\title{
Substrates available for colonic fermentation from oat, barley and wheat bread diets. A study in ileostomy subjects
}

\author{
BY ÅGOT LIA ${ }^{1}$, BIRGITTA SUNDBERG ${ }^{2}$, PER AMAN², ANN-SOFIE \\ SANDBERG ${ }^{3}$, GÖRAN HALLMANS ${ }^{4}$ AND HENRIK ANDERSSON ${ }^{1}$ \\ ${ }^{1}$ Department of Clinical Nutrition, University of Göteborg, Göteborg, Sweden \\ ${ }^{2}$ Department of Food Science, Swedish University of Agricultural Sciences, Uppsala, Sweden \\ ${ }^{3}$ Department of Food Science, Chalmers University of Technology, Göteborg, Sweden \\ ${ }^{4}$ Department of Nutritional Research, University of Umeå, Sweden
}

(Received 31 August 1995 - Revised 11 March 1996 - Accepted 5 April 1996)

\begin{abstract}
Nutrients not absorbed in the small bowel will form substrates for microbial growth in the colon which may have implications for the development of colon cancer. The aim of the present study was to investigate whether fibre-rich oat and barley diets increase the excretion of energy-supplying nutrients from the small bowel compared with a low-fibre wheat diet, and whether a possible increase could be related to the $\beta$-glucan content. Nine ileostomy subjects were served four types of bread together with a low-fibre basal diet $(12 \mathrm{~g}$ dietary fibre/d). The breads were based on either wheat flour ( $\mathrm{W}$ diet, $7 \mathrm{~g}$ dietary fibre/d), oat bran (OB diet, $29 \mathrm{~g}$ dietary fibre/d), the same amount of oat bran with addition of $\beta$-glucanase (EC 3.2.1.4) (OBE diet, $19 \mathrm{~g}$ dietary fibre/d) or a fibre-rich barley fraction (B diet, $35 \mathrm{~g}$ dietary fibre/d). An increased ileal excretion of starch was observed with the barley diet but no effect of the oat $\beta$-glucan on starch recovery was found. The NSP + Klason lignin in the ileostomy effiuents accounted only for $24,31,24$ and $35 \%$ of the gross energy excretion in the $W, O B, O B E$ and $B$ diet periods respectively. A large part of the dry weight and energy $(30,21,28$ and $27 \%$, in the $W, O B, O B E$ and $B$ diets respectively) in the effluents could not be identified as fat, protein, total starch or NSP + Klason lignin. This unidentified part was probably made up of oligosaccharides, endogenous losses and nutrient complexes. Methods for identifying and analysing these components should be developed and their role as substrates for colonic fermentation and colon cancer development ought to be investigated.
\end{abstract}

Oats: Barley: Ileostomy

In a meta-analysis of thirty-seven epidemiological studies, twenty-one of the studies supported a strong-to-moderate protective effect of high-fibre diets against colon cancer (Trock et al. 1990). Furthermore, twelve out of thirteen case-control studies showed an inverse relationship between dietary fibre intake ana risk of cancer in the colon and rectum (Howe et al. 1992), and recently, in an international comparison study, high starch intake was also inversely correlated to colorectal cancer risk (Cassidy et al. 1994).

There is an inverse correlation between faecal weight and colonic cancer frequency in different populations, implying that the growth of the colonic microflora is protective against malignancies (Cummings et al. 1992). Maintenance of the colonic microflora is dependent on the nutrients delivered from the small bowel. Malabsorbed nutrients from the small bowel consequently form the substrates for microbial growth in the colon.

NSP and starch are readily fermented in the colon with the production of short-chain fatty acids (SCFA) and various gases (Macfarlane \& Cummings, 1991). Of the SCFA, butyrate is an important fuel for the colonic epithelial cells (Roediger, 1980) and in-vitro studies have shown that the growth rate of colon cancer cells can be slowed down by 
butyrate (Kim et al. 1980). Fermentation of starch increases the amount of butyrate formed in relation to other SCFA (Scheppach et al. 1988).

The mixed-linked $(1 \rightarrow 3)$, $(1 \rightarrow 4)$ - $\beta$-D-glucans (in the present paper referred to as $\beta$ glucan) in oat and barley may, due to their viscous properties, influence absorption in the small intestine (Braaten et al. 1991; Wood et al. 1994; Lia et al. 1995). The digestibilities of oat bran, rolled oats and different barley fractions have earlier been studied in ileostomy subjects (Englyst \& Cummings, 1985; Áman et al. 1995; Livesey et al. 1995). Food structure was found to be an important determinant of barley grain digestibility in the small intestine (Livesey et al. 1995). However, the specific effect of $\beta$-glucan on the amount of nutrients entering the colon has, to our knowledge, not previously been studied. In the present study a $\beta$-glucan-degrading enzyme was used to study the effect of oat $\beta$-glucan on small bowel excretion in ileostomy subjects.

The aim was to investigate whether $\beta$-glucan-rich oat and barley diets increase the excretion of energy-supplying nutrients from the small bowel compared with a low-fibre wheat diet, and furthermore, to see whether a possible increase could be mediated by the $\beta$-glucan. This was investigated in ileostomy subjects served with four kinds of bread together with a basal diet. The breads were based on either wheat flour, oat, bran, oat bran with addition of $\beta$-glucanase $(E C 3.2 .1 .4)$ or a fibre-rich barley fraction. The sterol excretion from the small bowel with these diets has been presented in an earlier report (Lia et al. 1995).

\section{SUBJECTS AND METHODS}

\section{Subjects}

Nine subjects (six males and three females) with a median age of 57 (range 30-70) years and BMI of 24.6 (range $21 \cdot 1-27 \cdot 2$ ) $\mathrm{kg} / \mathrm{m}^{2}$ volunteered for the study. The subjects had been proctocolectomized for ulcerative colitis $1-23$ years earlier with only a minor portion of the terminal ileum removed. One of the subjects used antihypertensive drugs as well as thyroid substitute. In two other subjects the gallbladder was resected and they also used antihypertensive drugs. Apart from this, the participants were in good health without symptoms and signs of small-bowel inflammation or ileostomy dysfunction. The customary energy intake in the group was assessed by a $3 \mathrm{~d}$ dietary record, using household measures and estimated weights (g) of foods consumed. Median energy intake was 8585 (range 6590-16029) $\mathrm{kJ}$ of which 37 (range 31-41), 15 (range 12-18), 46 (range 37-52) and 2 (range 0-11) \% was from fat, protein, carbohydrate and alcohol respectively. Dietary fibre intake was 17 (range 10-24) g/d (according to the method of Asp et al. 1983). Calculation of nutrient intakes was made using the KOSTSVAR software package (AIVO AB, Stockholm, Sweden).

\section{Diets}

The subjects were served four different kinds of bread in random order in a crossover design. The bread supplied about $40 \%$ of the daily energy intake with the remainder made up by a constant basal diet adjusted to each subject's need determined from body weight $(140 \mathrm{~kJ} / \mathrm{kg}$; World Health Organization, 1985), a $24 \mathrm{~h}$ diet recall and a test day before the study. Each kind of bread was eaten for two consecutive days with $5 \mathrm{~d}$ between the diet periods. The breads were based on wheat flour (W), oat bran (OB) (Kungsörnen AB, Sweden) or a roller-dried fibre-rich barley fraction (B) (denoted M2 by Sundberg et al. 1995). The fourth kind of bread (OBE) was also made from oat bran but with the addition of $2 \mathrm{~g} \beta$-glucanase (GP 5000, Grindstedt Products A/S Braband, Denmark)/kg to the bread dough. The commercially available enzyme preparation was a purified $\beta$-glucanase ( 5000 units $/ \mathrm{kg}$ measured by a Grindstedt viscosimetric method) which also contained xylanase (EC 3.2.1.8) and pectinase (EC 3.2.1.15) activities. The bread dough was 
allowed to ferment for $180 \mathrm{~min}$ at about $37^{\circ}$ and for a further $50 \mathrm{~min}$ after rolls had been made. During the fermentation the amount of $\beta$-glucan (degree of polymerization (DP) $>$ 10 ) in the $\beta$-glucanase-supplemented bread decreased by about $70 \%$. The ingredients of the different breads (thirty rolls) were: W bread: wheat flour $1400 \mathrm{~g}$, margarine $30 \mathrm{~g}$, dry yeast $24 \mathrm{~g}$, sugar $20 \mathrm{~g}$, syrup $15 \mathrm{~g}$, salt $12 \mathrm{~g}$ and water $800 \mathrm{~g}$; OB bread: oat bran $675 \mathrm{~g}$, wheat flour $450 \mathrm{~g}$, wheat gluten $100 \mathrm{~g}$, dry yeast $30 \mathrm{~g}$, sugar $20 \mathrm{~g}$, syrup $15 \mathrm{~g}$, salt $12 \mathrm{~g}$ and water $1000 \mathrm{~g}$; OBE bread: same as the OB bread but with addition of $4 \mathrm{~g} \beta$-glucanase; $\mathrm{B}$ bread: fibre-rich barley fraction $830 \mathrm{~g}$, wheat flour $450 \mathrm{~g}$, wheat gluten $100 \mathrm{~g}$, margarine $34 \mathrm{~g}$, dry yeast $30 \mathrm{~g}$, sugar $20 \mathrm{~g}$, syrup $15 \mathrm{~g}$, salt $12 \mathrm{~g}$ and water $1720 \mathrm{~g}$.

The subjects were served six rolls of the OB, OBE or B breads daily, or four rolls daily of the $\mathrm{W}$ bread. The constant part of the diets consisted of creamed potatoes, a fish dish, a chicken dish, ham, turkey, margarine, honey, peach slices in syrup, cream and lowalcohol beer. Extra creamed potato and/or lemonade was added when more energy was requested. The food was prepared in a metabolic ward kitchen and kept frozen at $-20^{\circ}$ until the day of consumption. Duplicate portions of all the basal diets were freeze-dried and analysed. More details about the preparation and components of the diets are described elsewhere (Lia et al. 1995). The four diet periods will be referred to henceforth as the W diet, OB diet, OBE diet, and $B$ diet respectively. The OB and OBE diets differed only in the amount and DP of the $\beta$-glucan. The B diet contained similar amounts of $\beta$-glucan to those in the $\mathrm{OB}$ diet to allow comparison of the effects on sterol excretion (Lia et al. 1995). The nutrient contents of the basal diets and the daily bread portions are presented in Table 1.

\section{Procedure}

The subjects had a light evening meal the evening before each sampling period and nothing was consumed after 20.00 hours. On the experimental days the breakfast was served at 08.00 hours on the metabolic ward. The rest of the meals were eaten by the subject at home or work at 10.00 hours (coffee and bread), 12.30 hours (creamed potatoes, fish dish and bread), 17.00 hours (creamed potatoes, chicken dish and bread) and 20.00 hours (peach slices and cream). The ileostomy bags were changed every second hour from 08.00 to 23.00 hours and one or two bags were used between 23.00 and 08.00 hours the next day. The ileostomy bags were immediately sealed and frozen on solid $\mathrm{CO}_{2}$ in a transportable Dewar vessel. The subjects delivered the frozen bags to the metabolic ward where the contents were weighed, freeze-dried, pooled into $24 \mathrm{~h}$ samples and kept frozen at $-20^{\circ}$ until analysed.

\section{Chemical analysis}

Freeze-dried food and ileostomy samples were analysed by similar methods, unless otherwise specified. The energy content was determined by combustion in a bomb calorimeter (Gallenkamp Automatic Adiabatic Bomb Calorimeter, Loughborough, Leics.). $\mathrm{N}$ was analysed using a modified micro-Kjeldahl technique (Sandberg et al. 1981) and crude protein calculated as $\mathrm{N} \times 6.25$. Analysis of analytically enzyme-available starch (including free glucose, maltose and malto-oligosaccharides) was performed according to the method of Aman et al. (1994) and the analysis of dietary fibre as the sum of NSP, enzyme-resistant starch and Klason lignin by the method of Theander et al. (1995). The enzyme-resistant starch was analysed by the method of Westerlund et al. (1989) and the $\beta$ glucan according to Åman \& Graham (1987). Fat was hydrolysed, extracted and methylated in the same way as the bile acids according to Bosaeus \& Andersson (1987) and the fatty acid methyl ester fraction analysed as described previously (Lia et al. 1995). The amount of triacylglycerol was calculated assuming the fatty acids to account for approximately $94 \%$ of the total fat. 
Table 1. Nutrient content of the basal diet and bread portions in the four diet periods

\begin{tabular}{|c|c|c|c|c|c|}
\hline & \multirow{2}{*}{$\begin{array}{l}\text { Constant part* } \\
\text { Basal diet... }\end{array}$} & \multicolumn{4}{|c|}{ Variable part (bread) } \\
\hline & & w† & OB & OBE & B \\
\hline Gross energy $(\mathrm{kJ} / \mathrm{d})$ & $7530(5290-12250)$ & 3510 & 4640 & 4650 & 5160 \\
\hline Fat $(\mathrm{g} / \mathrm{d})$ & $80 \cdot 3(64 \cdot 4-91 \cdot 6)$ & $13 \cdot 9$ & $16 \cdot 1$ & $16 \cdot 1$ & $13 \cdot 5$ \\
\hline Protein $(\mathrm{g} / \mathrm{d})$ & $61 \cdot 3(54 \cdot 4-79 \cdot 4)$ & $26 \cdot 2$ & $57 \cdot 4$ & 57.5 & $53 \cdot 3$ \\
\hline Enzyme available starch $(\mathrm{g} / \mathrm{d}) \ddagger$ & $72.7(35 \cdot 6-92 \cdot 4)$ & 127.9 & $112 \cdot 5$ & $115 \cdot 0$ & $136 \cdot 7$ \\
\hline Dietary fibre $(\mathrm{g} / \mathrm{d}) \mathrm{s}$ & $12.5(8.3-20.0)$ & $6 \cdot 6$ & $29 \cdot 0$ & $19 \cdot 4$ & $35 \cdot 1$ \\
\hline Enzyme resistant starch (g/d) & $0.6(0-3-1.8)$ & $1 \cdot 4$ & $1 \cdot 1$ & $1 \cdot 1$ & $2 \cdot 2$ \\
\hline$\beta$-Glucan $(\mathrm{g} / \mathrm{d})$ & $0.5(0.3-0.6)$ & 0.7 & $12 \cdot 0$ & $3 \cdot 3$ & 12.4 \\
\hline
\end{tabular}

W, wheat diet; $O B$, oat bran diet; $O B E$, oat bran diet with $\beta$-glucanase $(E C$ 3.2.1.4); B, barley fibre diet.

* Median and range for nine subjects.

† Including $10 \mathrm{~g}$ margarine as spread.

† Determined in vitro by the analytical procedure (Åman et al. 1994).

$\S$ NSP, enzyme-resistant starch and Klason lignin.

\section{Calculation of dietary and stomal gross energy contents}

From gross energy values and nutrient analysis the proportions of energy from fat, protein, dietary fibre and other carbohydrates could be calculated. The energy conversion factors used were: $39.3 \mathrm{~kJ} / \mathrm{g}, 23.6 \mathrm{~kJ} / \mathrm{g}, 17.5 \mathrm{~kJ} / \mathrm{g}$ and $17 \mathrm{~kJ} / \mathrm{g}$ for the heat of combustion of fat, protein, dietary fibre and other carbohydrates respectively (Southgate \& Durnin, 1970).

\section{Statistics}

Data are presented as median and $95 \%$ confidence interval for the median (Altman, 1991). Wilcoxon matched pairs signed rank sum test was used for comparison of the excretion between day 1 and day 2 . No difference was observed and consequently the mean excretion for the $2 \mathrm{~d}$ was used in further analyses. Recovery was calculated as a percentage of intake. For comparison of the recoveries and excretion patterns between the four diet periods, Friedman two-way ANOVA by ranks was used and multiple pairwise comparisons of the ranks performed (Siegel \& Castellan, 1988). A non-parametric analysis of the data was chosen because the data did not follow a Gaussian distribution. Some individuals showed extensively deviating values in some of the variables. Differences were considered significant at $\boldsymbol{P}<0.05$ (two-sided test). No specific significance level was attainable from the ranking test. The statistical package Systat (1992) was used for the analyses.

\section{Ethical considerations}

The subjects gave informed consent and the study was approved by the Ethical Committee of Sahlgrenska Hospital.

\section{RESULTS}

The values for effluent collected and the gross energy and nutrient contents of the effluent are presented in Table 2 . The wet and dry weights of the effluents were significantly higher in the OB and $\mathrm{B}$ diet periods than the $\mathrm{W}$ diet period.

The excretion and recovery of gross energy and nutrients are presented in Table 2 and Table 3 respectively. A significantly higher fat recovery was observed in both the $O B$ and $\mathrm{OBE}$ diet periods compared with the $\mathrm{W}$ diet period. The recovery of $\mathrm{N}$ was significantly higher in the $\mathrm{OB}$ than in the $\mathrm{W}$ diet period.

The amount of starch resistant to digestion in the small intestine is here referred to as 
Table 2. The amounts of wet and dry matter, energy and nutrients in the ileostomy effluents from subjects consuming four different diets*

(Median values and 95\% confidence intervals for nine subjects)

\begin{tabular}{|c|c|c|c|c|}
\hline & \multicolumn{4}{|c|}{ Diet periods } \\
\hline & $\mathbf{w}$ & OB & OBE & B \\
\hline & Median $(95 \% \mathrm{CI})$ & Median (95\% CI) & Median (95\% CI) & Median (95\% CI) \\
\hline Wet wt $(g / d)$ & $517(399-775)$ & $890(686-1025)$ & $716(520-859)$ & $914(737-1023)$ \\
\hline Dry wt $(g / d)$ & $46.5(41-9-57 \cdot 8)$ & $91 \cdot 4(88 \cdot 3-105)$ & $80.5(72 \cdot 5-93 \cdot 2)$ & $98 \cdot 0(87.5-103 \cdot 6)$ \\
\hline Gross energy $(\mathrm{kJ} / \mathrm{d})$ & $870(710-990)$ & $1690(1610-1920)$ & $1510(1380-1740)$ & $1790(1520-1930)$ \\
\hline Fat $(g / d)$ & $0.8(0.6-1.0)$ & $5.5(4.6-6.0)$ & $4.7(3.0-5 \cdot 0)$ & $2 \cdot 0(1 \cdot 5-2 \cdot 5)$ \\
\hline Protein (g/d) & $11 \cdot 3(10-6-13 \cdot 8)$ & $22 \cdot 2(19 \cdot 7-25 \cdot 0)$ & $20 \cdot 0(18 \cdot 1-23 \cdot 1)$ & $20.6(17 \cdot 8-21 \cdot 6)$ \\
\hline $\begin{array}{l}\text { Enzyme available } \\
\text { starch }(\mathrm{g} / \mathrm{d}) \dagger\end{array}$ & $3 \cdot 2(2 \cdot 5-5 \cdot 1)$ & $2 \cdot 9(2 \cdot 8-5 \cdot 1)$ & $3 \cdot 4(2 \cdot 6-5-2)$ & $4.0(3.4-5.81)$ \\
\hline Dietary fibre $(\mathrm{g} / \mathrm{d}) \ddagger$ & $13 \cdot 7(11 \cdot 3-16.9)$ & $33.1(31 \cdot 0-34 \cdot 9)$ & $22 \cdot 8(20 \cdot 9 \cdot-28 \cdot 1)$ & $37 \cdot 0(33 \cdot 3-41 \cdot 7)$ \\
\hline $\begin{array}{c}\text { Enzyme resistant } \\
\text { starch }(\mathrm{g} / \mathrm{d})\end{array}$ & $2 \cdot 1(1 \cdot 7-2 \cdot 6)$ & $1.9(1.3-2.4)$ & $2 \cdot 2(1 \cdot 7-2 \cdot 6)$ & $2 \cdot 8(2 \cdot 3-3 \cdot 3)$ \\
\hline$\beta$-Glucans $(\mathrm{g} / \mathrm{d})$ & $0.4(0.3-0.4)$ & $10.9(10.4-11.6)$ & $2 \cdot 3(2 \cdot 1-2 \cdot 6)$ & $10 \cdot 8(9 \cdot 5-11 \cdot 0)$ \\
\hline
\end{tabular}

W, wheat diet; $O B$, oat bran diet; OBE, oat bran diet with $\beta$-glucanase (EC 3.2.1.4); B, barley fibre diet.

* For details of diets see Table 1.

$\dagger$ Determined in vitro by the analytical procedure (Åman et al. 1994).

$\ddagger$ NSP, enzyme-resistant starch and Klason lignin.

Table 3. Recovery (\%) of energy and nutrients in ileostomy effluents from subjects consuming four different diets, during a $24 \mathrm{~h}$ period*

(Median values and $\mathbf{9 5 \%}$ confidence intervals for nine subjects)

\begin{tabular}{|c|c|c|c|c|c|}
\hline & \multicolumn{4}{|c|}{ Diet periods } & \multirow[b]{3}{*}{$P+$} \\
\hline & $\mathbf{w}$ & OB & OBE & B & \\
\hline & Median (95\% CI) & Median (95\% CI) & Median (95\% CI) & Median $(95 \% \mathrm{CI})$ & \\
\hline Gross energy & $7 \cdot 7(6.8-8.6)^{a}$ & $14.8(12.8-15.8)^{b}$ & $12.9(11.4-14.2)^{\mathrm{ac}}$ & $14 \cdot 1(11 \cdot 6-15 \cdot 2)^{b c}$ & $<0.001$ \\
\hline Fat & $0.9(0.7-1.0)^{a}$ & $5.6(5.0-6.7)^{b}$ & $4.8(2 \cdot 1-5 \cdot 0)^{b}$ & $2 \cdot 3(1 \cdot 6-2 \cdot 7)^{\mathrm{ab}}$ & $<0.001$ \\
\hline Protein & $13.4(10.9-15-0)^{\mathrm{n}}$ & $17.8(16 \cdot 8-21 \cdot 5)^{b}$ & $17 \cdot 1(15 \cdot 0-18 \cdot 0)^{\mathrm{ab}}$ & $17 \cdot 1(15.9-18 \cdot 5)^{\mathrm{ab}}$ & $<0.001$ \\
\hline $\begin{array}{l}\text { Enzyme available } \\
\text { starch } \ddagger\end{array}$ & $1.6(1.4-2.4)^{2}$ & $1.6(1.5-2.5)^{\mathrm{ab}}$ & $1.8(1.4-2.4)^{\mathrm{ab}}$ & $2.0(1.6-2.6)^{b}$ & 0.009 \\
\hline Dietary fibre & $72 \cdot 1(66 \cdot 0-77 \cdot 8)^{8}$ & $81 \cdot 7(73 \cdot 7-84 \cdot 2)^{\mathrm{ab}}$ & $75 \cdot 2(67 \cdot 7-85 \cdot 3)^{\mathrm{ab}}$ & $79 \cdot 3(76 \cdot 2-85 \cdot 5)^{b}$ & 0.024 \\
\hline $\begin{array}{l}\text { Enzyme resistant } \\
\text { starch }\end{array}$ & $106(96 \cdot 1-115)^{2}$ & $111(82 \cdot 2-130)^{816}$ & $129(114-143)^{\mathrm{ab}}$ & $94.6(89 \cdot 1-106)^{b}$ & 0.003 \\
\hline$\beta$-Glucan & $35 \cdot 1(23 \cdot 8-38 \cdot 1)^{a}$ & $88.5(84.5-91.8)^{b}$ & $61 \cdot 2(58 \cdot 1-66 \cdot 7)^{\mathrm{ac}}$ & $82 \cdot 7(75 \cdot 4-88 \cdot 0)^{\mathrm{bc}}$ & $<0.001$ \\
\hline
\end{tabular}

$\mathrm{W}$, wheat diet; $\mathrm{OB}$, oat bran diet; OBE, oat bran diet with $\beta$-glucanase $(E C$ 3.2.1.4); B, barley fibre diet.

$a, b, c$ Different superscript letters denote a significant difference $(P<0.05$, two-tailed) between ranks when making multiple pairwise comparisons (Siegel \& Castellan, 1988).

* For details of diets see Table 1.

t Friedman two-way analysis of variance by ranks.

‡ Determined in vitro by the analytical procedure (Åman et al. 1994).

$\S$ NSP, enzyme-resistant starch and Klason lignin. 


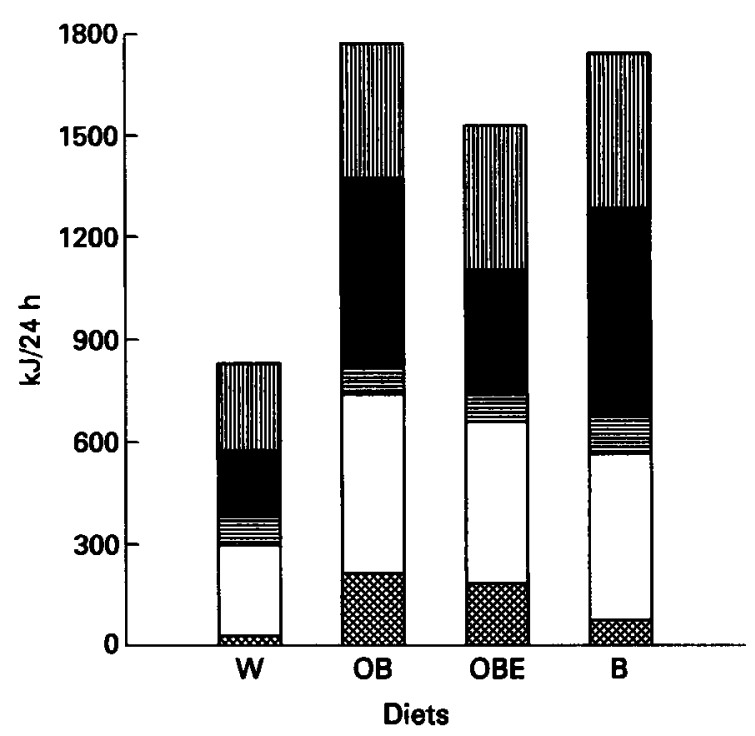

Fig. 1. The proportions of energy supplied by fat (ख, protein ( $\square$ ), total starch (目), NSP + Klason lignin ( $\square$ ) and the unidentified energy (四) excreted from the small bowel (median, $n$ 9). W, wheat diet; OB, oat bran diet; OBE, oat bran diet with $\beta$-glucanase $(E C$ 3.2.1.4); B, barley fibre diet. For details of diets and procedures, see Table 1 and pp. $798-800$.

total starch excretion and calculated as analytically enzyme-available starch plus enzymeresistant starch. Total starch excretion amounted to 4.9 (CI 4.3-7.5) g, 4.8 (CI 4.0-7.5) g, $5 \cdot 1$ (CI 4.5-7.7) g, 6.6 (CI 5.4-9.1) $\mathrm{g}$ in the $\mathrm{W}, \mathrm{OB}, \mathrm{OBE}$ and $\mathrm{B}$ diet periods respectively. These correspond to recoveries of $2 \cdot 6$ (CI 2.2-3.7) \%, 2.5 (CI 2.2-3.6) \%, 2.8 (CI 2.5-3.7) \% and 3.4 (CI $2.7-4.0) \%$ respectively. The recovery was higher in the B diet period than in the $\mathrm{OB}$ and $\mathrm{W}$ diet periods. Recovery of enzyme-available starch was higher in the $\mathrm{B}$ than in the $\mathrm{W}$ diet period.

The amounts of energy from fat, protein, total starch, NSP + Klason lignin and unidentified components in the effluents are presented in Fig. 1. The unidentified energy was calculated by difference. The median proportions of energy in the $W, O B, O B E$ and $B$ diet periods were: from fat $3 \cdot 8,11 \cdot 9,11 \cdot 0$ and $4.4 \%$; from protein $33 \cdot 2,30 \cdot 2,29.9$ and $27 \cdot 1 \%$; from total starch $10 \cdot 5,4 \cdot 8,5 \cdot 7$ and $6 \cdot 7 \%$; from NSP + Klason lignin $23 \cdot 6,30 \cdot 9,24 \cdot 2$ and $35 \cdot 1 \%$ and from unidentified energy $29 \cdot 9,21 \cdot 3,28 \cdot 6$ and $27 \cdot 5 \%$ respectively. There was a significant difference in energy proportions between the diet periods $(P<0.001$, Friedmans ANOVA).

\section{DISCUSSION}

The ileostomy model

Balance studies in ileostomy subjects can be performed within a few days because the mouth-to-stomal transit time is short and the day-to-day variation within the subjects is small (Tornqvist et al. 1986). The transit time through the small gut in ileostomy subjects is comparable with that in normal subjects (Holgate \& Read, 1983; Chapman et al. 1985; Englyst \& Cummings, 1985). However, there is a difference in the microbial population between a normal distal ileum $\left(10^{5}-10^{7}\right.$ bacteria/g) and the terminal ileum of ileostomy subjects $\left(10^{7}-10^{8}\right.$ bacteria/g) (Finegold et al. 1970; Drasar \& Hill, 1974). Provided the ileostomy bags are changed every $2 \mathrm{~h}$ and immediately frozen, the bacterial degradation of NSP and resistant starch is small (Sandberg et al. 1983; Englyst \& Cummings, 1985, 1987; 
Åman et al. 1995) and only small amounts of SCFA have been detected in the ileostomy effluent (Englyst \& Cummings, 1985; Bach-Knudsen \& Hessov, 1995). Few studies have been performed to investigate the possible postoperative adaptation of the small intestine to the loss of colonic functions. Absorption of electrolytes has been found to increase after proctocolectomy (Hill, 1976). However, the excretion of energy did not differ when comparing two groups of ileostomists given similar tube feeds in the early postoperative state and several months afterwards (Andersson et al. 1984a, b). Thus, the ileostomy model seems to be a useful model for studying the digestibility of nutrients in the small bowel.

\section{Starch recovery}

The $\beta$-glucan in oat bran did not affect the recovery of starch in the present study. The recoveries of enzyme-available starch in the $\mathrm{OB}, \mathrm{OBE}$ and $\mathrm{W}$ diet periods are comparable with the amounts found in earlier ileostomy studies with oat and wheat (Englyst \& Cummings, 1985; Åman et al. 1995). In a study of diets containing flaked and milled barley the particle size was found to be an important determinant of starch digestibility in the small bowel (Livesey et al. 1995). Starch recovery was $16.5 \%$ from flaked barley and $0.9 \%$ from milled barley (particle size $<250 \mu \mathrm{m}$ ) compared with the $2 \%$ recovery with the present barley fraction $(<800 \mu \mathrm{m})$. The higher recovery of both total and enzyme-available starch in the $B$ diet period compared with the $\mathrm{W}$ diet period may, thus, be explained by factors other than the content of $\beta$-glucan.

The fraction called enzyme-resistant starch in the present study is retrograded starch (mainly amylose) or the $\mathrm{RS}_{3}$ fraction according to the definition of Englyst et al. (1992). The recovery of enzyme-resistant starch is usually very close to $100 \%$ (Schweizer et al. 1990; Englyst et al. 1992; Åman et al. 1995). The explanation for a recovery of more than $100 \%$ of the enzyme-resistant starch in three of the four diet periods in the present study might be that the food portions consumed by the subjects were thawed and reheated before consumption. Reheating of potatoes (creamed potato was served here) will produce more enzyme-resistant starch (Englyst \& Cummings, 1987). The duplicate portions were only thawed before homogenizing and freeze-drying and could consequently contain less enzyme-resistant starch than that actually eaten by the subjects. Moreover, the deep freezing and/or freeze-drying processes may have increased the amount of enzyme-resistant starch in the food and effluents to different extents (Scheppach et al. 1991). The highest recovery was found in the OBE diet period which might also be explained by a possible effect of the enzyme treatment of the oat bran bread. It is to be observed, however, that the recoveries above $100 \%$ here, correspond to less than $1 \mathrm{~g}$ of enzyme-resistant starch.

\section{Excretion of fat and protein}

There was no difference in fat recovery in the $\mathrm{OB}$ and OBE diet periods despite extensive enzymic degradation of the $\beta$-glucan in the oat-bran bread in the latter period. This may be explained by the presence of fat in intact aleurone cell walls and maybe other types of cells in the oat bran that resist digestion in the small intestine and thereby act as barriers against digestive enzymes. The aleurone cell walls contain less $\beta$-glucan than the subaleurone layer and the starchy endosperm cell walls, and are therefore probably less sensitive to degradation by the enzyme preparation used (Webster, 1986).

The barley fraction was finely ground and contained less fat than the oat bran. This may explain the low fat excretion in the B diet period which was almost as low as in the wheat diet period. Physical characteristics rather than the $\beta$-glucan content could, thus, give a faecal loss of dietary fat. It is still to be determined, however, whether the fat excreted in the $\mathrm{OB}$ and $\mathrm{OBE}$ diet periods originates from the oat bran itself or from the rest of the diet.

The higher recovery of protein in the OB than in the W period could be an effect of the 
physical form of the food rather than the $\beta$-glucan or dietary fibre content (Chacko \& Cummings, 1988).

\section{Degradation of NSP and $\beta$-glucan}

The low recovery of NSP in all diet periods may be explained by bacterial degradation in the collecting bags and/or the terminal ileum of the ileostomy subjects. In a recent study the degradation of NSP in a barley diet took place almost exclusively in the night bags (Livesey et al. 1995). The recoveries were $95 \%$ and $70 \%$ at $12 \mathrm{~h}$ and $24 \mathrm{~h}$ respectively, compared with the $78 \%$ recovery $(24 \mathrm{~h})$ in the B diet period in the present study.

Reduced molecular weight of the $\beta$-glucan was observed both in the day and night bags in the present study (B. Sundberg, unpublished results) which indicates bacterial activity in the bags during the daytime as well. The degradation capacity might, however, be limited which could explain the difference in $\beta$-glucan recovery between the diet periods also reported by Åman et al. (1995).

In the present study the recoveries of galactose residues, probably mainly present in galactans of the creamed potatoes, were only $82,62,76$ and $74 \%$ for the $W, O B, O B E$ and B diet periods respectively. This indicates that NSP components other than $\beta$-glucan may also be degraded.

\section{Excretion of energy}

A part of the energy excreted from the small bowel will become available for the host through absorption of SCFA produced during fermentation in the large bowel (McNeil, 1984; Cummings et al. 1987). Faecal energy determinations from normal subjects with large variations in dietary fibre intake have been used to develop an equation from which the digestible energy from a given diet can be calculated (Livesey, 1991). Using this equation we estimate that $50 \%$ of the energy excreted from the small bowel in the OB and $\mathrm{B}$ diet periods and about $30 \%$ in the $\mathrm{W}$ diet period would become available to the host through fermentation in the colon. There might, however, be differences in the fermentability of the oat and barley dietary fibre compared with the mixed dietary fibre sources used in the development of the equation.

It is to be observed that the NSP + Klason lignin content in the ileostomy effluents only accounted for $24-35 \%$ of the gross energy excretion. If the recovery of NSP in the present study had been closer to $100 \%$, the NSP energy would still contribute less than $50 \%$ of the total energy excretion.

Another interesting observation in the present study is the large amount of energy, $21-30 \%$ of the gross energy, which could not be identified as fat, N, starch or dietary fibre. Although the figures were calculated by difference, we suggest that this energy is supplied by different forms of oligosaccharides, endogenous losses and carbohydrate degradation products not included in the starch and NSP analyses. Polysaccharide residues of endogenous origin are in some studies observed to be about 2-5 g/d (Englyst \& Cummings, 1985, 1987; Wolever et al. 1986; Schweizer et al. 1990). Very high intakes of cereal fibre as in the present study may give even greater endogenous losses. Some of this is, however, included in the dietary fibre analysis.

If we assume that the unidentified energy consisted of carbohydrates with an energy conversion factor of $17 \mathrm{~kJ} / \mathrm{g}$, the excretion was about $15,23,25$ and $27 \mathrm{~g}$ in the $\mathrm{W}, \mathrm{OB}$, $\mathrm{OBE}$ and $\mathrm{B}$ diet periods respectively. This means that considerable amounts of oligosaccharides, carbohydrate degradation products and endogenous losses could be excreted. In characterizing these carbohydrates it is, however, difficult to determine the total amount since only identified substances could be measured. Only the maltooligosaccharides are included in the starch analysis and for example lactose, sucrose, raffinose and fructo-oligosaccharides require separate analyses. The diets in the present 
Table 4. Composition of dry matter $(\mathrm{g} / 24 \mathrm{~h})$ in ileostomy effluent from subjects consuming four different diets*

(Median values for nine subjects)

\begin{tabular}{lrrrr}
\hline \hline & W & OB & OBE & B \\
\hline Analysed nutrients $\dagger$ & & & & \\
Unidentified energy transformed into g $\ddagger$ & $29 \cdot 0$ & 63.7 & $50 \cdot 9$ & 63.6 \\
Sum & 14.9 & 23.5 & 25.0 & 26.9 \\
Total dry weight & 43.9 & 87.2 & 75.9 & 90.5 \\
Difference & 46.5 & 91.4 & 80.5 & 98.0 \\
\hline
\end{tabular}

W, wheat diet; $\mathrm{OB}$, oat bran diet; $\mathrm{OBE}$, oat bran diet with $\beta$-glucanase $(E C$ 3.2.1.4); B, barley fibre diet.

* For details of diets, see Table 1.

† Sum of fat, protein, enzyme-available starch and dietary fibre from Table 2.

$\ddagger$ Calculated by difference from the energy excretion (total energy excretion - energy in analysed nutrients) and $17 \mathrm{~kJ} / \mathrm{g}$.

$\S$ Total dry weight - sum, assumed to be ash.

study contained large amounts of cereals and potatoes which contain different kinds of oligosaccharides. Oat bran and whole barley kernels both contain about $1 \%$ of oligosaccharides other than malto-oligosaccharides and sucrose (MacGregor \& Batty, 1993; Wood, 1993). Raffinose, gluco-difructose and other fructans are present. Wheat kernels contain $1.7 \%$ oligosaccharides mainly as gluco-difructose, gluco-fructosans and raffinose (Pomeranz, 1988). Another component in the diet was honey (40-60 g/d) which contains twenty different oligosaccharides in amounts up to 7.5\% (Swallow \& Low, 1990).

We analysed two of the effluent samples in the present study for sucrose, lactose, trehalose, raffinose, malto-hexose and gluco-difructose using the method of Carlsson et al. (1992). In total there was only about $\mathbf{0 . 3} \mathrm{g}$ in both an OB and B diet effluent. There are, however, still unidentified oligosaccharides. Nutrient complexes such as, for example, gluco-proteins and galacto-lipids may be present as well, and these will not be included in the analyses.

It is also to be observed that considerably more unidentified carbohydrates (calculated) were found in the oat and barley diet periods than in the wheat period which supports the idea that residues from the degradation of $\beta$-glucan could account for some of the unidentified energy as well. NSP with DP $<10$ are not included in the analyses.

In a study by Schweizer et al. (1990), 94-103\% of the dry effluent weight from potatoand bean-flake diets was identified by analysis of fat, protein, starch and "other carbohydrates' according to Dubois (1956). Separate analyses of sucrose, lactose, raffinose and stachyose accounted, however, for less than $50 \%$ of the 'other carbohydrates'. This indicates that other carbohydrates, probably oligosaccharides, were present as well. In the present study the weight of analysed nutrients and calculated weight of unidentified energy (calculated as carbohydrates, $17 \mathrm{~kJ} / \mathrm{g}$ ) accounted for $92-95 \%$ of the dry weight of the effluents (Table 4). The difference (2.6-7.5 g) corresponds to the amounts of ash observed in a similar study to be 5.3 and $6.6 \mathrm{~g}$ in the ileostomy content from a low-fibre and highfibre diet respectively (Sandberg et al. 1981). This calculation of substrates supports the idea that the amount of unidentified energy calculated as carbohydrates corresponds with the amount of unidentified dry matter.

The fact that the $\beta$-glucan in oat bran bread does not influence the digestibility of starch in the small bowel is one of the main findings of the present study. The increased starch recovery with the fibre-rich barley diet could probably be explained by factors other than 
the $\beta$-glucan content. Another finding was the considerable amounts of energy-supplying nutrients other than fat, protein, starch and dietary fibre excreted from the small bowel in all diet periods. We suggest these to be different kinds of oligosaccharides, nutrient complexes and endogenous losses. Methods for identifying and analysing these components should be developed and the role of carbohydrate components other than NSP and starch as substrates for colonic fermentation and colon cancer development ought to be investigated.

This study was supported by grants from the Swedish Council for Forestry and Agricultural Research, project number 50-0144/92.

\section{REFERENCES}

Altman, D. (1991). Practical Statistics for Medical Research, p. 535. London: Chapman and Hall.

Åman, P. \& Graham, H. (1987). Analysis of total and insoluble mixed-linked $(1 \rightarrow 3),(1 \rightarrow 4)-\beta$-D-glucans in barley and oats. Journal of Agricultural and Food Chemistry 35, 704-709.

Åman, P., Pettersson, D., Zhang, J.-X., Tidehag, P. \& Hallmans, G. (1995). Starch and dietary fiber components are excreted and degraded to variable extents in ileostomy subjects consuming mixed diets with wheat or oat bran bread. Journal of Nutrition 125, 2341-2347.

Åman, P., Westerlund, E. \& Theander, O. (1994). Determination of starch using a thermostable $\alpha$-amylase. In Methods in Carbohydrate Chemistry, pp. 111-115 [J. BeMiller, D. Manners and R. Surgeon, editors]. New York: John Wiley and Sons, Inc.

Andersson, H., Bosaeus, I., Ellegård, L., Hallgren, B., Hultén, L. \& Magnusson, O. (1984a). Comparison of an elemental and two polymeric diets in colectomized patients with and without intestinal resection. Clinical Nutrition 3, 183-189.

Andersson, H., Hultén, L., Magnusson, O. \& Sandström, B. M. (1984b). Energy and mineral utilization from a peptide-based elemental diet and a polymeric enteral diet given to ileostomists in the early postoperative course. Journal of Parenteral and Enteral Nutrition 8, 497-500.

Asp, N. G., Johansson, C. G., Hallmer, H. \& Siljeström, M. (1983). Rapid enzymatic assay of insoluble and soluble dietary fiber. Journal of Agricultural and Food Chemistry 31, 476-482.

Bach Knudsen, K. E. \& Hessov, I. (1995). Recovery of inulin from Jerusalem artichoke (Helianthus tuberosus L.) in the small intestine of man. British Journal of Nutrition 74, 101-113.

Bosaeus, I. \& Andersson, H. (1987). Short-term effect of two cholesterol-lowering diets on sterol excretion in ileostomy subjects. American Journal of Clinical Nutrition 45, 54-59.

Braaten, J. T., Wood, P. J., Scott, F. W., Riedel, K. D., Poste, L. M. \& Collins, M. W. (1991). Oat gum lowers glucose and insulin after an oral glucose load. American Journal of Clinical Nutrition 53, 1425-1430.

Carlsson, N. G., Karlsson, H. \& Sandberg, A. S. (1992). Determination of oligosaccharides in foods, diets, and intestinal contents by high-temperature gas chromatography and gas chromatography/mass spectrometry. Journal of Agricultural and Food Chemistry 40, 2404-2412.

Cassidy, A., Bingham, S. A. \& Cummings, J. H. (1994). Starch intake and colorectal cancer risk : an international comparison. British Journal of Cancer 69, 937-942.

Chacko, A. \& Cummings, J. H. (1988). Nitrogen losses from the human small bowel: obligatory losses and the effect of physical form of food. Gut 29, 809-815.

Chapman, R. W., Sillery, J. K., Graham, M. M. \& Saunders, D. R. (1985). Absorption of starch by healthy ileostomates: effect of transit time and of carbohydrate load. American, Journal of Clinical Nutrition 41, 1244-1248.

Cummings, J. H., Bingham, S. A., Heaton, K. W. \& Eastwood, M. A. (1992). Fecal weight, colon cancer risk, and dietary intake of nonstarch polysaccharides (dietary fiber). Gastroenterology 103, 1783-1789.

Cummings, J. H., Pomare, E. W., Branch, W. J., Naylor, C. P. E. \& Macfarlane, G. T. (1987). Short chain fatty acids in human large intestine, portal, hepatic and venous blood. Gut 28, 1221-1227.

Drasar, B. S. \& Hill, M. J. (1974). Human Intestinal Flora, pp. 36-43. London: Academic Press.

Dubois, M., Gilles, K. A., Hamilton, J. K., Rebers, P. A. \& Smith, F. (1956). Colorimetric method for determination of sugars and related substances. Analytical Chemistry 28, 350-356.

Englyst, H. N. \& Cummings, J. H. (1985). Digestion of the polysaccharides of some cereal foods in the human small intestine. American Journal of Clinical Nutrition 42, 778-787.

Englyst, H. N. \& Cummings, J. H. (1987). Digestion of polysaccharides of potato in the small intestine of man. American Journal of Clinical Nutrition 45, 423-431.

Englyst, H. N., Kingman, S. M. \& Cummings, J. H. (1992). Classification and measurement of nutritionally important starch fractions. European Journal of Clinical Nutrition 46, S33-S50.

Finegold, S. M., Sutter, V. L., Boyle, J. D. \& Shimada, K. (1970). The normal flora of ileostomy and transverse colostomy effluents. Journal of Infectious Diseases 122, 376-381. 
Hill, G. L. (1976). Ileostomy, Surgery, Physiology, and Management. New York: Grune and Stratton.

Holgate, A. M. \& Read, N. W. (1983). Relationship between small bowel transit time and absorption of a solid meal. Influence of metoclopramide, magnesium sulfate, and lactulose. Digestive Diseases and Sciences 28 , 812-819.

Howe, G. R., Benito, E., Castelleto, R., Cornée, J., Estève, J., Gallagher, R. P., Iscovich, J. M., Deng-ao, J., Kaaks, R., Kune, G. A., Kune, S., L'Abbé, K. A., Lee, H. P., Miller, A. B., Peters, R. K., Potter, J. D., Riboli, E., Slattery, M. L., Trichopoulos, D., Tuyns, A., Tzonou, A., Whittlemore, A. S., Wu-Williams, A. H. \& Zheng, S. (1992). Dietary intake of fiber and decreased risk of cancer of the colon and rectum: evidence from the combined analysis of 13 case-control studies. Journal of the National Cancer Institute 84, 1887-1896.

Kim, Y. S., Tsao, D., Siddiqui, B., Whitehead, J. S., Arnstein, P., Bennett, J. \& Hicks, J. (1980). Effects of sodium butyrate and dimethylsulfoxide on biochemical properties of human colon cancer cells. Cancer 45, 1185-1192.

Lia, A., Hallmans, G., Sandberg, A. S., Sundberg, B., Åman, P. \& Andersson, H. (1995). Oat $\beta$-glucan increases bile acid excretion and a fibre-rich barley fraction increases cholesterol excretion. A study in ileostomy subjects. American Journal of Clinical Nutrition 62, 1245-1251.

Livesey, G. (1991). Calculating the energy values of foods: towards new empirical formulae based on diets with varied intakes of unavailable complex carbohydrates. European Journal of Clinical Nutrition 45, 1-12.

Livesey, G., Wilkinson, J. A., Roe, M., Faulks, R., Clark, S., Brown, J. C., Kennidy, H. \& Elia, M. (1995). Influence of the physical form of barley grain on the digestion of its starch in the human small intestine and implications for health. American Journal of Clinical Nutrition 61, 75-81.

Macfarlane, G. T. \& Cummings, J. H. (1991). The colonic flora, fermentation, and large bowel digestive function. In The Large Intestine: Physiology, Pathophysiology and Disease, pp. 51-91 [S. F. Philips, J. H. Pemberton and R. G. Shorter, editors]. New York: Raven Press, Ltd.

MacGregor, A. W. \& Batty, R. S. (1993). Barley, Chemistry and Technology. St Paul, MN: American Association of Cereal Chemists, Inc.

McNeil, N. I. (1984). The contribution of the large intestine to energy supplies in man. American Journal of Clinical Nutrition 39, 338-342.

Pomeranz, Y. (1988). Wheat Chemistry and Technology. St Paul, MN: American Association of Cereal Chemists, Inc.

Roediger, W. E. W. (1980). Role of anaerobic bacteria in the metabolic welfare of the colonic mucosa in man. Gut 21, 793-798.

Sandberg, A. S., Ahderinne, R., Andersson, H., Hallgren, B. \& Hultén, L. (1983). The effects of citrus pectin on the absorption of nutrients in the small intestine. Human Nutrition: Clinical Nutrition 37C, 429-440.

Sandberg, A. S., Andersson, H., Hallgren, B., Hasselblad, K. \& Isaksson, B. (1981). Experimental model for in vivo determination of dietary fibre and its effect on the absorption of nutrients in the small intestine. British Journal of Nutrition 45, 283-294.

Scheppach, W., Bach, M., Bartram, P., Christl, S., Bergthaller, W. \& Kasper, H. (1991). Colonic fermentation of potato starch after a freeze-thaw cycle. Digestive Diseases and Sciences 36, 1601-1605.

Scheppach, W., Fabian, C., Sachs, M. \& Kasper, H. (1988). Effect of starch malabsorption on fecal SCFA excretion in man. Scandinavian Journal of Gastroenterology 23, 755-759.

Schweizer, T. F., Andersson, H., Langkilde, A. M., Reimann, S. \& Torsdottir, I. (1990). Nutrients excreted in the ileostomy effluents after consumption of mixed diets with bread and potatoes. II. Starch, dietary fibre and sugars. European Journal of Clinical Nutrition 44, 567-575.

Siegel, S. \& Castellan, N. J. (1988). Nonparametric Statistics for the Behavioral ,Sciences, 2nd ed. Singapore: McGraw-Hill Book Co.

Southgate, D. A. T. \& Durnin, J. V. G. A. (1970). Calorie conversion factors. An experimental reassessment of the factors used in the calculation of the energy value of human diets. British Journal of Nutrition 24, 517-535.

Sundberg, B., Pettersson, D. \& Aman, P. (1995). Nutritional properties of fibre-rich barley products fed to broiler chickens. Journal of the Science of Food and Agriculture 67, 469-476.

Swallow, K. W. \& Low, N. H. (1990). Analysis and quantitation of the carbohydrates in honey using highperformance liquid chromatography. Journal of Agricultural and Food Chemistry 38, 1828-1832.

Systat (1992). Systat for Windows: Statistics, Version 5 Edition. Evanston, IL: Systat, Inc.

Theander, O., Åman, P., Westerlund, E., Andersson, R. \& Pettersson, D. (1995). Total dietary fiber determined as neutral sugar and uronic acid residues, and lignin (the Uppsala method): collaborative study. Journal of the Association of Official Analytical Chemists 78, 1030-1044.

Tornqvist, H., Rissanen, A. \& Andersson, H. (1986). Balance studies in patients with intestinal resection. British Journal of Nutrition 56, 11-16.

Trock, B., Lanza, E. \& Greenwald, P. (1990). Dietary fiber, vegetables, and colon cancer : critical review and metaanalyses of the epidemiologic evidence. Journal of the National Cancer Institute 82, 650-661.

Webster, F. H. (cditor) (1986). Oats, Chemistry and Technology. St Paul, MN: American Association of Cereal Chemists, Inc.

Westerlund, E., Theander, O., Andersson, R. \& Åman, P. (1989). Effects of baking on polysaccharides in white bread fractions. Journal of Cereal Science 10, 149-156.

Wolever, T. M. S., Cohen, Z., Thompson, L. U., Thorne, M. J., Jenkins, M. J. A., Prokipchuk, E. J. \& Jenkins, D. J. A. (1986). Ileal loss of available carbohydrate in man: comparison of a breath hydrogen method with direct measurement using a human ileostomy model. American Journal of Gastroenterology 81, 115-122. 
Wood, P. J. (editor) (1993). Oat Bran. St Paul, MN: American Association of Cereal Chemists, Inc.

Wood, P. J., Braaten, J. T., Scott, F. W., Riedel, D. K., Wolynetz, M. S. \& Collins, M. W. (1994). Effect of dose and modification of viscous properties of oat gum on plasma glucose and insulin following an oral glucose load. British Journal of Nutrition 72, 731-743.

World Health Organization (1985). Energy and Protein Requirements. WHO Technical Report Series no. 724. Geneva: WHO. 